\title{
Preterm labour and its effect on perinatal morbidity and mortality
}

\author{
Neetu Gupta $^{1}$, Pragati Divedi $^{1 *}$, Deepti Dwivedi ${ }^{2}$
}

\begin{abstract}
${ }^{1}$ Department of Obstetrics and Gynecology, UPUMS, Saifai, Etawah, Uttar Pradesh, India
\end{abstract}
${ }^{2}$ Department of Physiology, GSVM, Kanpur, Uttar Pradesh, India

Received: 19 February 2018

Accepted: 27 March 2018

*Correspondence:

Dr. Pragati Divedi,

E-mail: drpragati_divedi@yahoo.com

Copyright: (C) the author(s), publisher and licensee Medip Academy. This is an open-access article distributed under the terms of the Creative Commons Attribution Non-Commercial License, which permits unrestricted non-commercial use, distribution, and reproduction in any medium, provided the original work is properly cited.

\section{ABSTRACT}

Background: This study was performed to find out the incidence and identification of risk factors of preterm labour and also to find out the incidence of perinatal outcome in the form of morbidity and mortality.

Methods: Total 720 antenatal cases with preterm labour admitted and studied in total one-year duration in UPUMS Saifai, Etawah. Out of 720 cases, 692 pregnant patients underwent preterm birth. Thorough history taking, general, systemic and obstetrical examination was done for each patient. APGAR Score and birth weights of the new borns were noted at the time of birth and they were followed up throughout the hospital stay. Incidence and perinatal morbidity and mortality of preterm births were calculated.

Results: Incidence of preterm labour and births were $28.5 \%$ and $27.9 \%$ respectively. Among various causes of preterm birth, spontaneous labour with intact membranes is the most common cause. Lack of antenatal check-up was found to be most common risk factor of preterm labour followed by infection and low socioeconomic status. Majority of the new-borns had low APGAR score $(<6)$ in the present study. Total perinatal morbidity in the present study group was $67.2 \%$

Conclusions: We concluded that higher incidence of perinatal morbidity and mortality may be due to that the study was conducted at tertiary health care hospital which mostly receive high risk cases and majority of cases belonged to low socioeconomic group and also that the incidence of perinatal morbidity and mortality may be more in this part of country.

Keywords: Preterm labour, Perinatal morbidity and mortality

\section{INTRODUCTION}

Preterm labour is defined by WHO as the onset of labour prior to the completion of 37 weeks of gestation. ${ }^{1}$ Preterm labour is a syndrome characterized by premature activation of the final pathway of parturition and causing approximately $30 \%$ of all preterm birth. Preterm labour has multiple causes like chorioamniotic infection is responsible for $20-40 \%$ of all cases of preterm birth. ${ }^{1}$ Approximatly $5-10 \%$ of patients in preterm labour have infection outside uterus, most commonly in urinary tract. Another extra uterine infection is gingivitis. ${ }^{2}$ Abnormal placentation, foetal and maternal stress. ${ }^{3}$ Stress response in human beings is regulated by the hypothalamic secretion of corticotropin releasing hormone(CRH). Foetus stress is possibly the cause of preterm birth in pregnancies with a foetus affected by a congenital, metabolic or infectious disease. ${ }^{4}$ Bleeding in decidual chorionic interface. Vaginal bleeding is frequently the first sign of a sequence of events leading to preterm birth. Preterm labour is also common with abruption placenta and placenta previa. Risk factors for preterm labour includes demographic characteristic (age $<17$ years to $>35$ years, non-white races, low socioeconomic status, low pre-pregnancy weight), behavioural factors, stressful life style and previous preterm labour. Preterm birth is a 
leading cause of morbidity and mortality in both developed and developing countries. Four major reasons of preterm births are preterm labour (causes and risk factors of preterm labour already described), premature rupture of membranes (PROM), indicated preterm delivery (most common conditions requiring preterm birth are preeclampsia, severe foetal growth restriction due to uteroplacental insufficiency, antepartum hemmorhage, placenta previa, abruption placentae, Rhisoimmunization, maternal diabetes, chronic hypertension, chronic renal disease etc.) and incompetent cervix.

Preterm labour complicates 5-10\% of pregnancies and is a leading cause of morbidity and mortality. Preterm infants are at risk for developing numerous medical problems like respiratory complications (like respiratory distress syndrome, chronic lung disease and bronchopulmonary dysplasia etc.), cardiovascular (patent ductus arteriosus), neurological (hypoxic ischemic encephalopathy, intraventricular hemmorhage, retinopathy of prematurity etc), gastrointestinal and metabolic (necrotizing enterocolitis, rickets of prematurity etc.), haematological (anaemia of prematurity, thrombocytopenia, hyperbilirubineimia etc.) complications etc. Recent evidences suggest that early identification of at risk pregnancies with timely referral for specialized obstetrical care may help identify women at risk for preterm labour and decrease the extreme prematurity rate thereby reducing the morbidity and mortality rates.

\section{METHODS}

Total 720 antenatal women with preterm labour at less than 37 weeks gestational age admitted and studied. Out of 720 cases, 692 pregnant patients underwent preterm birth in our Department of Obstetrics and Gynaecology, UPUMS, Saifai Hospital from October 2015 to September 2016.

\section{Inclusion criteria}

- $\quad<37$ weeks and >20 weeks of gestational age,

- Singleton pregnancy,

- All booked and un booked patients,

- Either vaginal preterm or caesarean delivery.

\section{Exclusion criteria}

- Malpresentation

- Multi foetal gestation

- Pregnancy beyond 37 weeks.

Each patient was subjected to thorough history taking, general physical examination, systemic examination and obstetrical examination paying special attention to presence or absence of conventional risk factors for preterm labour. Investigations like routine, urine, vaginal culture sensitivity, $\mathrm{C}$ reactive protein, LFT (liver function tests), KFT (kidney function tests), NST (non-stress test), USG (for gestational age, liquor, congenital anomaly etc.) were done. APGAR scores and birth weights of the new borns were noted at the time of birth and they were followed up throughout the hospital stay. Incidence and perinatal morbidity and mortality of preterm birth were calculated.

\section{RESULTS}

The present study was conducted in 720 antenatal cases with preterm labour to identify risk factors and to assess the perinatal morbidity and mortality in preterm labour and birth.

Table 1: Incidence of preterm labour and preterm birth.

\begin{tabular}{|c|c|c|c|c|c|}
\hline \multirow[t]{2}{*}{ Preterm labour } & \multicolumn{5}{|c|}{ Preterm birth } \\
\hline & Total & Incidence (\%) & & Total & Incidence (\%) \\
\hline $\begin{array}{l}\text { Total antenatal cases admitted } \\
\text { during study period }\end{array}$ & 2520 & \multirow{2}{*}{$28.5 \%$} & $\begin{array}{l}\text { Total antenatal cases } \\
\text { delivered during study } \\
\text { period (term and preterm) }\end{array}$ & 2480 & \multirow{2}{*}{$27.9 \%$} \\
\hline $\begin{array}{l}\text { Antenatal cases with preterm } \\
\text { labour admitted during the study } \\
\text { period }\end{array}$ & 720 & & $\begin{array}{l}\text { Antenatal cases with } \\
\text { preterm labour delivered } \\
\text { during study period }\end{array}$ & 692 & \\
\hline
\end{tabular}

Table 1 showing incidence of preterm labour and preterm birth. In our study we found incidence of preterm labour $28.5 \%$ and incidence of preterm birth $27.9 \%$.

Table 2 showing risk factors of preterm labour. Lack of antenatal check-up was found to be most important risk factor in $78.5 \%$ of cases followed by infection to be the most important risk factor in $57.7 \%$ of cases. $56.3 \%$ of patients belonged to low socio-economic status, $43.3 \%$ of patients were involved in heavy work demanding long standing hours, $15.2 \%$ of patients have weight $(<45 \mathrm{~kg})$ and $11.6 \%$ of patients had height $(145 \mathrm{~cm}), 18.8 \%$ of 
patients had history of previous abortion, $11.6 \%$ of patient had history of prior preterm birth and $18 \%$ patients had history of prior pregnancy loss.

Table 2: Risk factors of preterm labour $(n=720)$.

\begin{tabular}{|lll|}
\hline Risk factors & No. & $\%$ \\
\hline Lack of antenatal check-ups & 566 & 78.6 \\
\hline Infection & 416 & 57.7 \\
\hline Low socioeconomic status & 406 & 56.3 \\
\hline Heavy work & 312 & 43.3 \\
\hline Previous abortions & 136 & 18.8 \\
\hline Pre-pregnancy loss & 130 & 18 \\
\hline Weight (<45kg) & 110 & 15.2 \\
\hline Height (<145 cm.) & 84 & 11.6 \\
\hline Previous preterm birth & 84 & 11.6 \\
\hline Family history & 8 & 1.1 \\
\hline Smoking & 4 & 0.5 \\
\hline
\end{tabular}

Table 3 shows distribution of preterm babies according to APGAR score at birth. We found that majority of neonates $(45.3 \%)$ have APGAR score between 4-6 $(\leq 6)$ in the present study. Neonates having APGAR of 7-10 were $43.3 \%$ while neonates with APGAR $<3$ were $11.4 \%$.

Table 3: Distribution of preterm babies according to Apgar score at birth (APGAR score of live born babies at birth $(n=559)$.

\begin{tabular}{|lll|}
\hline Apgar score & Number & Percentage \\
\hline $7-10$ & 242 & 43.3 \\
\hline $4-6$ & 253 & 45.3 \\
\hline$<3$ & 64 & 11.4 \\
\hline
\end{tabular}

Table 4 showing neonatal outcome in live born babies (n $=559$ ). In the present study we found that out of 559 live born, $239(42.75 \%)$ babies were healthy and required no resuscitation. $320(57.24 \%)$ babies shifted to neonatology intensive care unit (NICU) in which 119 (21.8\%) babies recovered and shifted back to ward and 201 (35.95\%) babies expired in NICU.

Table 4: Neonatal outcome in live birth babies $(n=559)$.

\begin{tabular}{|lll|}
\hline Total & No. & $\%$ \\
\hline healthy babies & 239 & 42.75 \\
\hline $\begin{array}{l}\text { Neonates shifted to NICU } \\
\text { (Neonatalogy intensive care unit) }\end{array}$ & 320 & 57.24 \\
\hline $\begin{array}{l}\text { Babies expired in NICU within 7 } \\
\text { days }\end{array}$ & 201 & 35.95 \\
\hline $\begin{array}{l}\text { Babies recovered and shifted back to } \\
\text { ward }\end{array}$ & 119 & 21.28 \\
\hline
\end{tabular}

Table 5 showing neonatal morbidity. Total perinatal morbidity in our study is $67.2 \%$. In our study we found that out of 559 live born neonates $320(57.24 \%)$ babies were shifted to NICU, $56(17.5 \%)$ were diagnosed having respiratory distress syndrome on clinical grounds. 20
(6.2\%) babies were diagnosed having intraventricular hemorrhage.

Table 5: Neonatal morbidity $(n=320)$.

\begin{tabular}{|lll|}
\hline Morbidity & No. & $\%$ \\
\hline Neonatal hyperbilirubinemia (NNH) & 60 & 18.7 \\
\hline Respiratory distress syndrome (RDS) & 56 & 17.5 \\
\hline Hypoxic ischemic encephalopathy (HIE) & 46 & 14.3 \\
\hline Sepsis & 30 & 9.3 \\
\hline Intraventricular hemorrhage (IVH) & 20 & 6.2 \\
\hline Other (congenital anamoly, anemia etc.) & 04 & 1.3 \\
\hline
\end{tabular}

$60(18.7 \%)$ babies developed jaundice within first 24 hours. 30(9.3\%) babies developed sepsis. 46 (14.3\%) babies developed HIE (Hypoxic ischemic encephalopathy), rest 4 neonates had no obvious cause.

Table 6: Incidence of perinatal mortality.

\begin{tabular}{|lll|}
\hline Perinatal mortality & Number & $\%$ \\
\hline Total perinatal mortality & 402 & 52.8 \\
\hline Still born & 201 & 26.4 \\
\hline Early neonatal mortality & 201 & 26.4 \\
\hline
\end{tabular}

Table 6 showing perinatal mortality. Incidence of perinatal mortality is $52.8 \%$ in present study. Incidence of early neonatal death is $26.4 \%$ in present study.

\section{DISCUSSION}

Preterm birth is the major cause of perinatal morbidity and mortality. In our study, total 720 antenatal patients with preterm labour admitted during the study period.

In the present study the incidence of preterm labour and preterm birth were $28.5 \%$ and $27.9 \%$ respectively. Uma S et al showed incidence of preterm labour and preterm birth around $22 \%$ and $20.9 \%$ respectively, which is less when compared with the present study. ${ }^{2}$ Chandraharan E et al showed incidence of preterm labour around 6-15\%, which is quite less when when compared to the present study (28.5\% in the present study). ${ }^{3}$ Faye-Peterson OM, Baby Centre India and Ross MG showed incidences of preterm birth to be $5-13 \%, 11-14 \%$ and $20.9 \%$ respectively, which is less when compared with incidence of preterm birth in the present study $(27.9 \%) .^{4-6}$

In the present study we observed $57.7 \%$ of cases had infection which is consistent to other studies. Pandey $\mathrm{K}$ et al found that infection was associated with $65.5 \%$ of cases. $^{7}$ Incidence of risk factors of lack of antenatal checkups and low socioeconomic groups were $78.6 \%$ and $56.3 \%$ respectively. Similar results have been reported by Pandey $\mathrm{K}$ and Meis and collegues. ${ }^{7,8}$

In the present study we found that majority of neonates had low APGAR score $(<6)$ as shown in Table 3. Present findings are supported by Begum F, Bukshaw K, Pandey 
JN found that mean birth weight and APGAR scores of babies were lower. ${ }^{3}$ In the present study we found that incidences of respiratory distress syndrome (RDS) $17.5 \%$, hyperbilirubinemia (NNH) 18.7\%, hypoxic ischemic encephalopathy (HIE) $14.3 \%$ as shown in Table 5. Sehgal et al showed in their study that neonatal hyperbilirubinemia $(78 \%)$, RDS $(65 \%)$ were the most common causes of morbidity. ${ }^{9}$ Singh et al showed intraventricular hemmorhage was the most common cause of death $(42 \%)$ followed by sepsis $(31 \%) .{ }^{10}$ In the present study we found incidence of perinatal mortality around $52.8 \%$ as shown in Table 6. Singh et al and Singh Uma et al showed incidence of perinatal mortality around $21 \%$ and $12.7 \%$ respectively, which is quite less when compared with the present study (incidence of perinatal mortality in our study $52.8 \%) .{ }^{10,2}$

\section{CONCLUSION}

Authors concluded that higher incidence of perinatal mortality is because the study is conducted at rural tertiary health care hospital which mostly receives high risk cases and majority of cases belonged to low socioeconomic group and also that the incidence of perinatal mortality may be more in this part of country.

\section{ACKNOWLEDGMENTS}

Authors express their heartfelt gratitude to their colleagues and to their PG students of Obstetrics and Gynaecology Department for collecting data and undoubtedly to the antenatal patients without whom this work could not have been possible.

Funding: No funding sources Conflict of interest: None declared

Ethical approval: The study was approved by the Institutional Ethics Committee

\section{REFERENCES}

1. American college of Obstetrics and Gynaecologists. Preterm labour, Technical bulletin. Washington D.C. ACOG. 1995:206.

2. Uma $\mathrm{S}$, Nisha $\mathrm{S}$, Shikha $\mathrm{S}$. A prospective analysis of etiology and outcome of preterm labour. J Obstet Gynaecol India. 2007;57(1):48-52.

3. Chandraharan E, Kumaran SA. Recent advances in management of preterm labour. J Obstet Gynaecol India. 2005;55(2):118-9.

4. Faye-Peterson OM. The placenta in preterm birth. J Clin Pathol. 2008;61(12):1261-75.

5. Baby Centre India. Premature labour and birth. Dep. 2010. Available https://www.babycenter.in/a557706/prematurelabour-and-birth

6. Ross MG. Preterm labour. University of Calfornia. Preterm labour. April, 2011.

7. Pandey K, Ajay B, Neena G, Geetanjaly K. Predictive value of various risk factors for preterm labour. J Obstet Gynecol India. 2010;60(2):141-5.

8. Begum F, Buckshe K, Pande JN. Risk factors associated with preterm labour. Bangladesh Med Res Counc Bull. 2003;29(2):59-66.

9. Sehgal A, Telang S, Pareah SM. Maternal profile and immediate outcome in extremely low birth weight babies. Delhi Trop Doct. 2004;34:165-8.

10. Singh D, Varghere PV, Singh S. Outcome of hospitalized out born preterm babies. Indian $\mathbf{J}$ Maternal Child Health. 1992;3:4-7.

Cite this article as: Gupta N, Divedi P, Dwivedi D. Preterm labour and its effect on perinatal morbidity and mortality. Int J Reprod Contracept Obstet Gynecol 2018;7:1993-6. 